\title{
Certyfikacja pojazdów szynowych narzędziem do spełnienia wymagań bezpieczeństwa i interoperacyjności
}

\begin{abstract}
$W$ artykule przedstawiono proces certyfikacji wyrobu w kontekście etapów charakterystycznych dla pojazdu szynowego oraz wskazano źródta wymagań $i$ stosowane dokumenty odniesienia. Ukazano miejsce procesu certyfikacyjnego $w$ całokształcie postępowania merytorycznego i formalnego majacego na celu dopuszczenie pojazdu szynowego do eksploatacji na sieci kolejowej w Polsce. Zaprezentowano algorytm procesu certyfikacyjnego zaprojektowanego z przeznaczeniem dla Ośrodka Certyfikacji w Instytucie Pojazdów Szynowych „,TABOR" w Poznaniu.
\end{abstract}

\section{Wstęp}

Kolejnictwo jako publiczny rodzaj transportu masowego zdaje się przeżywać renesans w nowej odmienionej technicznie formule. Wzrost prędkości narzuca ostrzejsze wymagania $\mathrm{w}$ zakresie bezpieczeństwa a podwyższenie komfortu podróżowania wymaga szerokiego zastosowania elektroniki, automatyki, klimatyzacji i systemów diagnostycznych. Składy pociąó́w realizują coraz większe przebiegi dobowe, co wymaga niezawodności taboru. $\mathrm{W}$ związku $\mathrm{z}$ rozszerzeniem zakresu kursowania pociaggów poza granice krajowe państw członkowskich Unii Europejskiej (UE) a niekiedy i dalej, znaczenia nabiera problem współpracy $z$ urządzeniami infrastruktury kolejowej oraz taborem innych operatorów. Aspekty te wymusiły wprowadzenie przez Unię Europejską uregulowań uniwersalnych w postaci dyrektyw [1],[2],[3],[4], traktujących kolejnictwo jako system z podziałem na podsystemy. Jednym z podsystemów jest tabor kolejowy, będący przedmiotem działalności statutowej Instytutu Pojazdów Szynowych „TABOR” w Poznaniu.

Każdy pojazd szynowy, jako element podsystemu, podlega nadzorowi właściwej krajowej agendy rządowej, odpowiedzialnej za dopuszczenie pojazdu do eksploatacji na krajowej sieci kolejowej. W Polsce taką funkcję spełnia Urząd Transportu Kolejowego (UTK), działający w ramach Ministerstwa Infrastruktury. Dokumentem formalnym zezwalającym na dopuszczenie do ruchu na sieci Polskich Linii Kolejowych (PLK) jest świadectwo wydawane przez UTK. Podstawą wydania przez UTK świadectwa dopuszczenia są dwa rodzaje dokumentów: dokumenty odniesienia określające wymagania dla przedmiotowego pojazdu (Techniczne Standardy Interoperacyjności TSI, normy europejskie - EN, Karty UIC) oraz dokumenty będące dowodami, że pojazd wymagania te spełnia (raporty z badań oraz opinie opracowane przez niezależne, akredytowane, autoryzowane $\mathrm{i}$ notyfikowane laboratoria, np. w Instytucie Pojazdów Szynowych „TABOR” w Poznaniu).

Takie postępowanie zawiera w sobie dwa aspekty: akt formalnego wydania świadectwa dopuszczenia do ruchu przez UTK, niosący odpowiedzialność państwa za bezpieczeństwo przewozów oraz poprzedzający go proces certyfikowania wyrobu (pojazdu).

\section{Etapy charakterystyczne dla pojazdu szynowego}

Zaistnienie pojazdu szynowego bierze początek, gdy na rynku przewozów pojawi się zapotrzebowanie na określony rodzaj przewozów pasażerskich lub towarowych. Taka potrzeba pojawia się zwykle w świadomości zainteresowanego przewoźnika lub organu władzy np. samorządowej. Etap ten wymaga analiz planistycznych, technicznych i ekonomicznych, przyjmujących formy oficjalnych dokumentów, podlegających uzgodnieniom i zatwierdzeniu.

Końcowym etapem charakterystycznym dla pojazdu szynowego jest likwidacja, recykling lub utylizacja, następująca po wieloletniej eksploatacji, gdy pojazd wyczerpał swoje możliwości i przestał spełniać stawiane wymagania.

Całościowe zestawienie etapów charakterystycznych dla pojazdu szynowego przedstawiono $\mathrm{w}$ tabeli 1 . Każdy z etapów obejmuje określone procesy i kończy się ich udokumentowaniem.

Wśród procesów, na szczególną uwagę, z punktu widzenia kompleksowej oceny pojazdu, zasługuje proces certyfikacji (Lp. 8). Na uwagę zasługuje także fakt, iż w realizację znaczącej części procesów związanych z pojazdem szynowym zaangażowany jest $\mathrm{w}$ całości lub częściowo Instytut Pojazdów Szynowych „TABOR”. Udział ten jest zaznaczony w tabeli 1 wythuszczonym drukiem. 
Tabela 1

\begin{tabular}{|c|c|c|c|}
\hline Lp. & Etap & Realizator & Dokumenty \\
\hline 1. & $\begin{array}{l}\text { Określenie zapotrzebowania } \\
\text { rynku }\end{array}$ & $\begin{array}{l}\text { Zainteresowany przewoźnik lub } \\
\text { organ władzy }\end{array}$ & $\begin{array}{l}\text { Analizy rynku, plany rozwoju i } \\
\text { finansów regionu }\end{array}$ \\
\hline 2. & $\begin{array}{l}\text { Określenie wymagań klienta } \\
\text { (przewoźnika) }\end{array}$ & $\begin{array}{l}\text { Przewoźnik jako inwestor } \\
\text { zamawiający pojazd }\end{array}$ & $\begin{array}{l}\text { Specyfikacja techniczno- ekonomiczna } \\
\text { pojazdu }\end{array}$ \\
\hline 3. & $\begin{array}{l}\text { Określenie wymagań } \\
\text { operatora sieci kolejowej }\end{array}$ & $\begin{array}{l}\text { Właściciel infrastruktury } \\
\text { kolejowej (w Polsce PKP-PLK) } \\
\text { na podstawie dyrektyw UE } \\
\text { (Techniczne Standardy } \\
\text { Interoperacyjności) }\end{array}$ & $\begin{array}{l}\text { Specyfikacja wymagań: } \\
\text { interoperacyjności, bezpieczeństwa, } \\
\text { energochłonności, komfortu i ekologii } \\
\text { wg TSI }\end{array}$ \\
\hline 4. & $\begin{array}{l}\text { Określenie możliwości } \\
\text { technicznych, technolog. } \\
\text { materiałowych }\end{array}$ & $\begin{array}{l}\text { Jednostka projektowa } w \\
\text { systemie zarządzania jakością } \\
\text { PN-ISO } 9001\end{array}$ & $\begin{array}{l}\text { Studium koncepcyjne pojazdu } \\
\text { uzgodnione } z \text { inwestorem }\end{array}$ \\
\hline 5. & $\begin{array}{l}\text { Opracowanie dokumentacji } \\
\text { projektowej }\end{array}$ & $\begin{array}{l}\text { Jednostka projektowa } w \\
\text { systemie zarządzania jakością } \\
\text { PN-ISO } 9001\end{array}$ & $\begin{array}{l}\text { Dokumentacja techniczna niezbędna } \\
\text { dla wyprodukowania pojazdu }\end{array}$ \\
\hline 6. & $\begin{array}{l}\text { Wyprodukowanie pojazdu, } \\
\text { testy odbiorcze }\end{array}$ & $\begin{array}{l}\text { Producent we współpracy z } \\
\text { poddostawcami w SZJ PN-ISO } \\
9001 \text { lub IRIS }\end{array}$ & $\begin{array}{l}\text { Atesty materiałowe, świadectwa } \\
\text { odbiorcze, protokoły prób i testów }\end{array}$ \\
\hline 7. & $\begin{array}{l}\text { Badania laboratoryjne } \mathrm{i} \\
\text { eksploatacyjne }\end{array}$ & $\begin{array}{l}\text { Laboratorium akredytowane, } \\
\text { autoryzowane, notyfikowane } \\
\text { wg PN-EN ISO/IEC } 17025 \\
\end{array}$ & Raporty z badań \\
\hline 8. & $\begin{array}{l}\text { Certyfikacja obowiązkowa } \\
\text { lub dobrowolna }\end{array}$ & $\begin{array}{l}\text { Jednostka certyfikująca } \\
\text { wyroby, akredytowana, } \\
\text { autoryzowana, notyfikowana } \\
\text { wg PN-EN } 45011\end{array}$ & $\begin{array}{l}\text { Specyfikacja techniczno-ekonomiczna } \\
\text { pojazdu. Specyfikacja wymagań: } \\
\text { interoperacyjności, bezpieczeństwa, } \\
\text { komfortu i ekologii wg TSI. } \\
\text { Analizy, Obliczenia, Interpretacje, } \\
\text { Opinie, Oceny. } \\
\text { Certyfikat zgodności }\end{array}$ \\
\hline 9. & Dopuszczenie do ruchu & $\begin{array}{l}\text { Agenda rządowa odpowiedzialna } \\
\text { za bezpieczeństwo ruchu. } \\
\text { (W Polsce Urząd Transportu } \\
\text { Kolejowego). }\end{array}$ & $\begin{array}{l}\text { Rozporządzenia Ministra Infrastruktury } \\
{[9,11]} \\
\text { Analizy, Obliczenia, Interpretacje, } \\
\text { Opinie, Oceny. } \\
\text { Świadectwo dopuszczenia }\end{array}$ \\
\hline 10. & $\begin{array}{l}\text { Eksploatacja i utrzymanie } \\
\text { pojazdu }\end{array}$ & $\begin{array}{l}\text { Przewoźnik- wg Dokumentacji } \\
\text { Technicznych Standardów } \\
\text { Utrzymania } \\
\end{array}$ & $\begin{array}{l}\text { DTSU, zapisy przebiegów, przeglądów, } \\
\text { awarii, napraw }\end{array}$ \\
\hline 11. & $\begin{array}{l}\text { Modernizacja pojazdu } \\
\text { (jeżeli to uzasadnione) }\end{array}$ & $\begin{array}{l}\text { Jednostka projektowa } w \\
\text { systemie zarządzania jakością } \\
\text { PN-ISO } 9001\end{array}$ & $\begin{array}{l}\text { Studium koncepcyjne pojazdu } \\
\text { uzgodnione } z \text { inwestorem } \\
\text { Dokumentacja Techniczna niezbędna } \\
\text { dla modernizacji }\end{array}$ \\
\hline 12. & Wykonanie modernizacji & Jak w p.6 & Jak w p.6 \\
\hline 13. & Badania & Jak w p.7 & Jak w p.7 \\
\hline 14. & Certyfikacja & Jak w p.8 & Jak w p.8 \\
\hline 15. & Dopuszczenie & Jak w p.9 & Jak w p.9 \\
\hline 16. & $\begin{array}{l}\text { Likwidacja, recykling, } \\
\text { utylizacja }\end{array}$ & $\begin{array}{l}\text { Przewoźnik oraz } \\
\text { wyspecjalizowane jednostki wg } \\
\text { stosownych dyrektyw }\end{array}$ & $\begin{array}{l}\text { Protokoły likwidacji pojazdu } \\
\text { Potwierdzenia recyklingu i utylizacji }\end{array}$ \\
\hline
\end{tabular}

\section{Proces certyfikacji wyrobu}

Certyfikacja wyrobu polega na porównaniu wyspecyfikowanych wymagań dla danego wyrobu z wynikami niezależnych jego badań oraz formalnym potwierdzeniu spełnienia wymagań. Instytucja przeprowadzająca proces certyfikowania wyrobów winna spełniać wymagania normy [5], potwierdzone akredytacją krajo- wej jednostki akredytującej (Polskie Centrum Akredytacji - PCA) oraz zgodnie z ustawą [6],[7] uzyskać autoryzację (udzielaną w imieniu Ministerstwa Infrastruktury przez Urząd Transportu Kolejowego) oraz notyfikację UE. 
Z definicji certyfikacji wynika, że certyfikat zgodności jest warunkiem merytorycznym i koniecznym, ale nie wystarczającym dla dopuszczenia pojazdu do ruchu. Niezbędny jest jeszcze krok merytoryczno formalny zawierający akt podjęcia odpowiedzialności państwa za stan bezpieczeństwa; a więc świadectwo dopuszczenia do ruchu.

Z brzemienności skutków dopuszczenia pojazdu do ruchu wywodzą się wymagania normy [5] dotyczące jednostek certyfikujących i personelu przez nie zatrudnionego.

Certyfikacja pojazdów szynowych i ich zespołów związana $\mathrm{z}$ dopuszczeniem do ruchu, obejmująca bezpieczeństwo ruchu oraz interoperacyjność wynikającą $z$ dyrektyw unijnych dla kolejnictwa[1,2,3,4] jest obowiązkowa. Certyfikacja

dobrowolna może być wykonywana $\mathrm{z}$ inicjatywy producenta i służyć promocji wyrobu na rynku celem zaprezentowania go potencjalnemu użytkownikowi.

\section{Polityka w dziedzinie certyfikacji wyrobów}

Polityka dotycząca certyfikacji wyrobów - pojazdów szynowych jest pochodną wymagań prawnych $[6,7,8]$ wyrażających odpowiedzialność władz państwowych za bezpieczeństwo i interoperacyjność w ruchu kolejowym na obszarze kraju zgodnie z dyrektywami UE $[1,2,3,4]$. Wymagania systemowe $\mathrm{w}$ odniesieniu do certyfikacji wyrobów określa norma [5]. Instytucje i osoby zajmujące się certyfikowaniem wyrobów winny dysponować dużą wiedzą i doświadczeniem w dziedzinie taboru kolejowego $\mathrm{w}$ aspektach takich jak: konstrukcja, obliczenia, projektowanie, rozwój, modernizacje, wykonawstwo nowatorskich rozwiązań, badania, analizy, ekspertyzy, oceny, opiniowanie i doradztwo.

Klientami, zainteresowanymi certyfikacją swoich wyrobów są jednostki zajmujące się produkcją, modernizacją i naprawami oraz eksploatacją taboru szynowego w kraju i poza granicami. Klienci oczekuja zwykle konsultacji merytorycznych, profesjonalnej obsługi i przyjaznej współpracy.

Ośrodek Certyfikacji Wyrobów winien mieć na celu działanie na rzecz klientów w dziedzinie certyfikacji pojazdów szynowych i ich zespołów, co jest niezbędnym elementem promowania transportu szynowego oraz bezpiecznej i przyjaznej dla pasażera i środowiska eksploatacji.

Ośrodek Certyfikacji Wyrobów, podlega bezpośrednio Dyrektorowi Instytutu, mając zapewnioną osobowością prawną, autonomię organizacyjną, możliwość angażowania niezależnego personelu i nie podlega żadnym zewnętrznym i wewnętrznym naciskom organizacyjnym i finansowym. Pracami Ośrodka kieruje Główny Specjalista ds. Certyfikacji Wyrobów. Proces certyfikacji wyrobów jest zgodny $\mathrm{z}$ wymaganiami normy PN-EN 45011:2000.

\section{Przebieg procesu certyfikacji wg [5] i [10]}

Zgodnie z [5] możliwość zgłoszenia swojego wyrobu (pojazdu lub zespołu) do certyfikacji ma każdy producent. Natomiast nie może uczestniczyć w procesie certyfikacji osoba będąca konstruktorem, projektantem bądź producentem przedmiotowego wyrobu oraz uczestnicząca $w$ jego badaniach. Przestrzeganie tej zasady jest podstawą zachowania bezstronności i niezależności procesu.

Kolejne kroki postępowania w zaprojektowanym procesie przedstawiono w algorytmie, rys.1.

Proces certyfikacji wyrobu jest usługą płatną w oparciu o umowę pomiędzy stronami. Podpisanie umowy winno nastapić możliwie na początku procesu, jednak na etapie pozwalającym na oszacowanie niezbędnego zakresu prac, a szczególnie ewentualnego podzlecania badań, wykonania analiz specjalistycznych itp. W uzasadnionych przypadkach, można stosować wówczas aneksowanie wcześniej spisanej umowy. Proces certyfikacji zawarto w 12 krokach:

Krok 1. Analiza zamówienia lub zapytania klienta wyrażającego zamiar poddania określonego wyrobu certyfikacji, jest wykonywana w Ośrodku Certyfikacji Wyrobów (NC) pod kątem wymagań i możliwości realizacji.

Krok 2. Jeżeli certyfikowanie okazuje się możliwe, NC przesyła do klienta informator i druk wniosku o przeprowadzenie certyfikacji wyrobu. W przeciwnym wypadku NC wysyła pismo informując klienta o niemożności certyfikowania z podaniem uzasadnienia.

Krok 3. Klient składa wniosek, który winien spełniać wymagania zawarte $\mathrm{w}$ informatorze.

Krok 4. NC dokonuje przeglądu wniosku na zgodność z kryteriami i warunkami certyfikacji.

Krok 5. Jeżeli wniosek spełnia wymagania formalne, $\mathrm{NC}$ opracowuje plan oceny. W przeciwnym wypadku wniosek wraca do klienta celem uzupełnienia.

Krok 6. W oparciu o plan oceny, NC wyznacza kompetentnych specjalistów, dokumentem powołania zatwierdzonym przez Dyrektora Instytutu. NC nie wyznacza takich ekspertów, którzy byli związani z projektowaniem lub innym postępowaniem związanym z certyfikowanym wyrobem i mogliby być nieobiektywni w swoich ocenach. Specjaliści analizuja przedstawione przez klienta dokumenty celem ustalenia czy zachodzi potrzeba podzlecania badań.

Krok 7. Jeżeli zachodzi potrzeba, NC w porozumieniu z klientem podzleca badania $\mathrm{w}$ zakresie niezbędnym dla dokonania oceny wyrobu, względnie klient zleca badania we własnym zakresie.

Krok 8. NC kompletuje dokumenty niezbędne dla oceny wyrobu takie jak raporty z badań, obliczenia, analizy, dokumentacja konstrukcyjna oraz kryteria oceny zawarte w TSI, normach Kartach UIC i innych opracowaniach. 


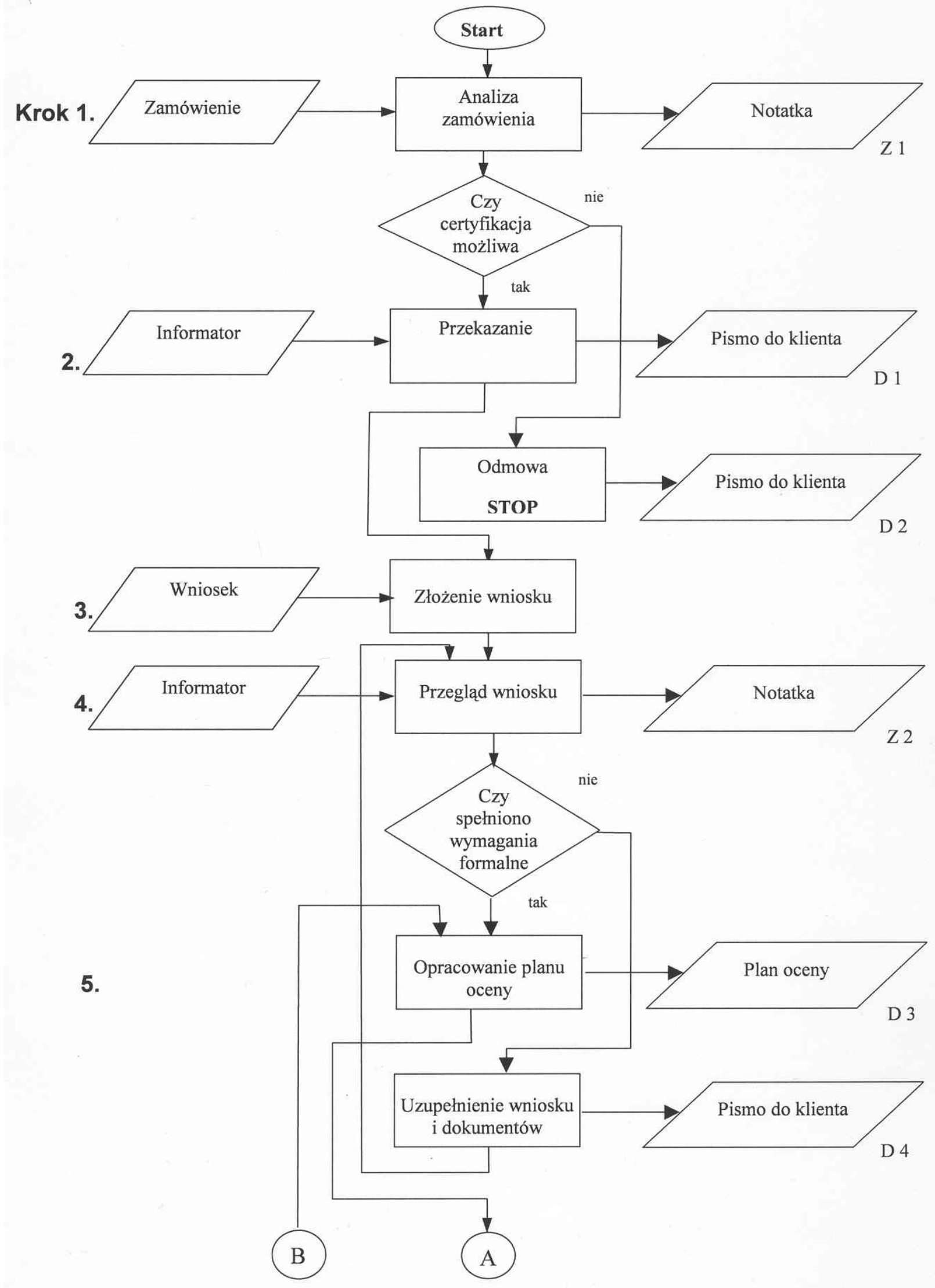




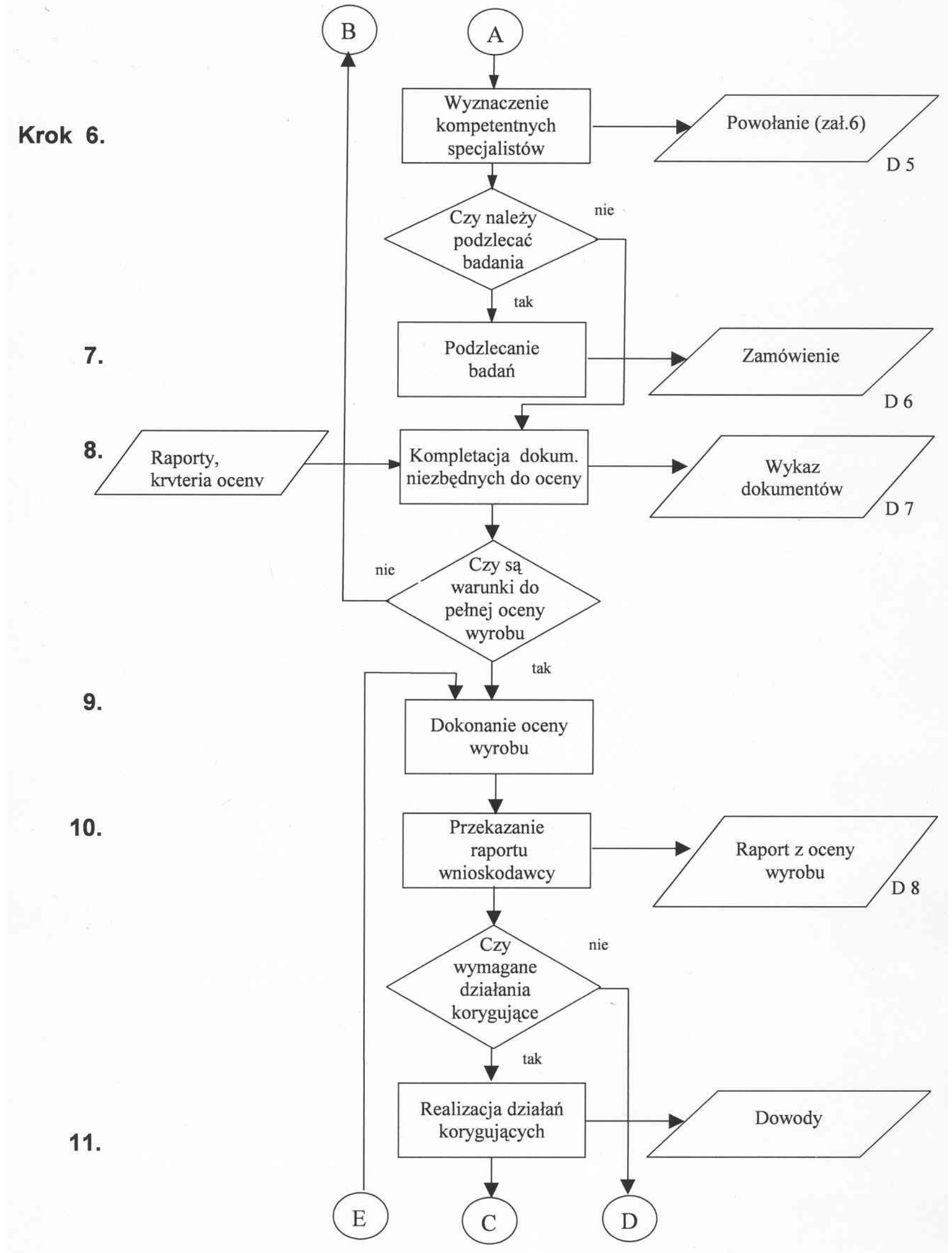




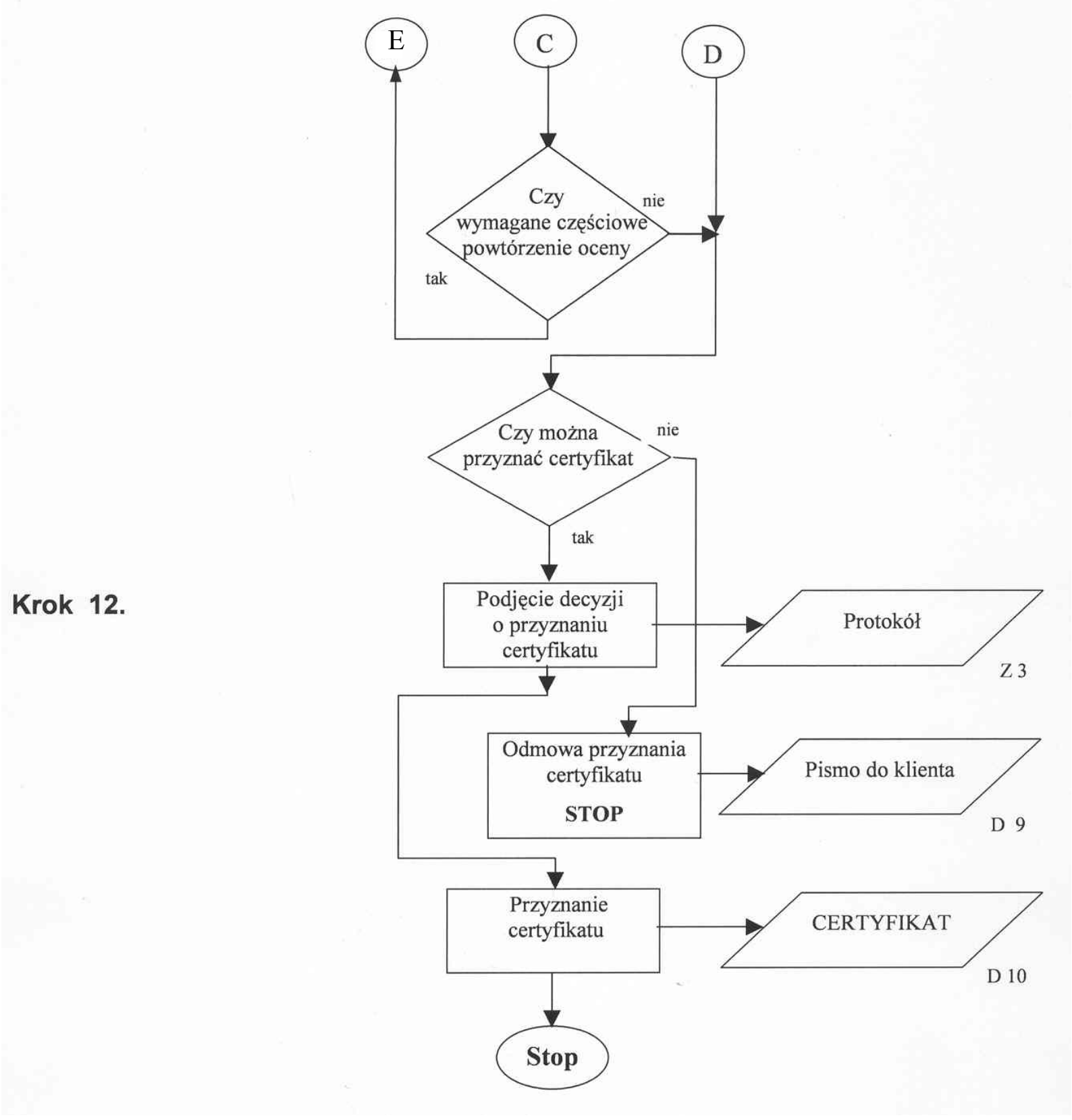

Rys. 1 Algorytm procesu certyfikacji wyrobów

Krok 9. Opracowanie ocen cząstkowych jest wykonywane przez powołanych niezależnych ekspertów. Jeżeli zgromadzono niezbędne materiały źródłowe, opracowuje się całościową ocenę wyrobu w formie raportu. Raport podpisują autorzy ocen cząstkowych oraz Główny Specjalista ds. Certyfikacji wyrobów. Raport zawiera zestawienie ocen cząstkowych w konfrontacji z kryteriami i wymaganiami oraz ocenę końcową zgodności wyrobu.

W przypadku ocen negatywnych, raport zawiera wykaz niezgodności cech zidentyfikowanych $\mathrm{z}$ wymaganymi, których usunięcie warunkuje ocenę pozytywną.
Krok 10. Przekazanie raportu z oceny wyrobu klientowi, następuje na zasadach poufności niezależnie od wyniku postępowania oceniającego.

Krok 11. Jeżeli raport wymaga wykonana działań korygujących, to klient zobowiązany jest przedstawić dowody, że wprowadzono niezbędne zmiany wynikające $\mathrm{z}$ raportu. Jeżeli wymagane jest częściowe powtórzenie oceny, postępowanie wraca do kroku 9.

Krok 12. Jeżeli nie występują przeszkody w nadaniu certyfikatu, zespół oceniający pod przewodnictwem Głównego Specjalisty ds. Certyfikacji Wyrobów podejmuje decyzję o przyznaniu certyfikatu zgodności. Certyfikat podpisuje Główny Specjalista ds. Certyfikacji Wyrobów oraz Dyrektor Instytutu. 


\section{Zapisy związane z procesem certyfikacji wyro- bów}

Każdy krok postępowania certyfikacyjnego winien być udokumentowany w celeu umożliwienia odtworzenia działań w przypadku ewentualności wystapienia skargi klienta, awarii lub katastrofy pojazdu. Poniżej wyspecyfikowano zapisy dokumentujące kolejne kroki procesu, oznaczając je symbolami Z1, Z2, Z3, występującymi w algorytmie - rys.1.

Z1. Notatka $\mathrm{z}$ analizy zamówienia lub pisma od klienta. Postać niesformalizowana, wykonuje Główny Specjalista ds. Certyfikacji Wyrobów jako dowód przeanalizowania wystapienia klienta. Zawiera konkluzję niezbędną dla odpowiedzi klientowi na pytanie „Czy certyfikacja jest możliwa?”.

Z2. Notatka z przeglądu wniosku o certyfikację złożonego przez klienta, na zgodność z wymaganiami zawartymi w Informatorze. Wykonuje Główny Specjalista ds. Certyfikacji Wyrobów. Zawiera konkluzję niezbędną dla odpowiedzi na pytanie ,Czy wniosek spełnia wymagania formalne?"

Z3. Protokół z posiedzenia zespołu ekspertów pod przewodnictwem Głównego Specjalisty ds. Certyfikacji Wyrobów, zawierający konkluzję o przyznaniu lub odmowie przyznania certyfikatu dla przedstawionego wyrobu. Zawiera podpisy wszystkich ekspertów i przewodniczącego zespołu.

\section{Dokumenty związane $z$ procesem certyfikacji wyrobów}

Kolejne etapy decyzyjne realizacji procesu wymagaja opracowania dokumentów, będących podstawą w postępowaniu formalnym. Dokumenty te sa sygnowane $\mathrm{w}$ imieniu Instytutu posiadającego osobowość prawną i odpowiedzialność za wydawane certyfikaty. $\mathrm{Na}$ rys.1 dokumenty oznaczono symbolem D1 - D10.

D1. Pismo do klienta potwierdzające możliwość podjęcia przez IPS-NC certyfikacji zgłoszonego wyrobu. W tym przypadku przesyła się w załączeniu informator o warunkach certyfikacji i druk wniosku.

D2. Pismo do klienta informujące o braku możliwość podjęcia przez IPS-NC certyfikacji zgłoszonego wyrobu. Pismo winno zawierać uzasadnienie.

D3. Plan oceny - opracowuje NC. Plan zawiera zestawienie czynności oceny wyrobu w strukturze tematyczno - terminowej z wyszczególnieniem badań niezbędnych do oceny.

D4. Pismo do klienta pismo z prośbą o uzupełnienie wniosku, jeżeli wniosek posiada luki formalne.

D5. Dokument powołania ekspertów technicznych dla dokonania cząstkowych

ocen wyrobu przygotowuje NC a zatwierdza DN.

D6. Pismo podzlecające wykonanie badań niezbędnych do oceny wyrobu.
D7. Wykaz dokumentów niezbędnych dla dokonania oceny raporty z badań oraz

dokumenty normatywne zawierające kryteria oceny.

D8. Raport z oceny wyrobu opracowany przez członków zespołu oceniającego. Raport zawiera uwagi wskazujące na niespełnienie wymagań lub zawiera ocenę pozytywną wyrobu, która jest podstawą do wydania certyfikatu zgodności wyrobu.

D9. Pismo do klienta informujące i uzasadniające odmowę udzielenia certyfikatu.

D10.Certyfikat zgodności wyrobu podpisany przez Głównego Specjalistę ds. Certyfikacji Wyrobów i Dyrektora Instytutu.

\section{Warunki udzielania, utrzymywania, rozszerza-} nia, zawieszania i cofania certyfikatu

1) Jednostka Certyfikująca dokonuje certyfikacji wyrobów w dziedzinie pojazdów szynowych poprzez porównanie wyników badań i analiz z wymaganiami przyjętymi dla oceny danego wyrobu w postępowaniu zgodnym z normą [5].

2) Badania wyrobu lub eksploatacja nadzorowana muszą być wykonywane lub nadzorowane przez akredytowane laboratoria badawcze. Badania zleca wnioskodawca lub za jego zgodą Jednostka Certyfikująca.

3) Klient występuje do Jednostki Certyfikującej w formie wniosku (na druku Jednostki Certyfikującej), który winien zawierać:

-Określenie firmy zgłaszającej wyrób do certyfikacji, nazwę, adres i status prawny.

-Określenie wyrobu, który ma być certyfikowany, system certyfikacji i normy, na zgodność z którymi wyrób ma być certyfikowany.

-Wnioskowany zakres certyfikacji.

-Zgodę wnioskodawcy na spełnienie wymagań certyfikacyjnych oraz na dostarczenie wszelkich informacji niezbędnych do oceny wyrobu.

-Podpis upoważnionego przedstawiciela wnioskodawcy na arkuszu zasadniczym jak i na ewentualnych załącznikach.

4) Certyfikacja jest przedmiotem umowy dwustronnej określającej cenę, termin i pozostałe szczegóły certyfikacji.

5) Udzielanie certyfikacji punkt 4.6 normy [5]

Udzielanie certyfikacji na wyrób następuje, jeżeli nie występują sprzeczności między wymaganiami a wynikami badań decydującymi o ich spełnieniu, oraz gdy są zachowane warunki formalne.

6) Utrzymywanie certyfikatu jest warunkowane terminem jego wydania lub udokumentowanym brakiem odstępów w zachowaniu się wyrobu w eksploatacji w stosunku do wymagań.

7) Rozszerzanie certyfikacji jest możliwe wg postępowania wg Części A oraz spełnieniu wymagań dotyczących poszerzonego zakresu zgłoszonego we wniosku, przy braku sprzeczności wymagań wcześniejszych i dotyczących rozszerzenia. 
8) Zawieszenie certyfikacji występuje do czasu wykonania i potwierdzenia realizacji działań korygujących wynikłych ze stwierdzonych niezgodności wyrobu z wymaganiami $\mathrm{w}$ okresie objętym certyfikatem. Zawieszenie jest oznajmiane pisemnie wnioskodawcy i publikowane jeśli to konieczne.

9) Cofnięcie certyfikatu następuje na warunkach jak w p.4 gdy zachodzi brak perspektyw na przywrócenie wyrobowi cech określonych w certyfikacie a działania nie mogą być zrealizowane lub są nieopłacalne.

10) Klientowi przysługuje składanie reklamacji, skargi w odniesieniu do procesu certyfikacji w terminie 2 lat od zakończenia procesu certyfikacji.

\section{Nadzór nad wyrobem certyfikowanym}

Potrzeba stosowania nadzoru nad wyrobem certyfikowanym wynika z konieczności eliminacji przypadków nadużywania znaku certyfikacji wyrobu, wykorzystywania wyrobu niezgodnie $\mathrm{z}$ przeznaczeniem oraz wynikłych z tego tytułu ewentualnych zagrożeń, stosując następujące zasady:

1) Nadzór nad wyrobem certyfikowanym polega na gromadzeniu i analizie informacji o zachowaniu się wyrobu w eksploatacji i spełnianiu warunków zgodności z kryteriami zapisanymi w certyfikacie.

2) Nadzór wynika $z$ odpowiedzialności jednostki certyfikującej za zachowanie zgodności wyrobu z certyfikatem oraz wykazaniu w razie konieczności, że ewentualne nieprawidłowości w funkcjonowaniu wyrobu leżą po stronie niewłaściwej eksploatacji lub zmian w procesie produkcji.

3) Zmiany właściwości wyrobu w stosunku do standardu określonego $\mathrm{w}$ certyfikacie, lub niespełnienie wymagań potwierdzonych $\mathrm{w}$ certyfikacie mogą wynikać z czynników, takich jak:

-Zmiany konstrukcyjne.

-Zmiany materiałów, podzespołów lub części.

-Zmiany technologiczne.

-Niewłaściwa obsługa.

-Niezgodne z założeniami zastosowanie wyrobu.

-Stosowanie niewłaściwych materiałów eksploatacyjnych.

-Niezgodne z założeniami warunki pracy.

4) Wymienione wyżej zmiany i odstępstwa są niedopuszczalne. Mogą być wprowadzane tylko za wiedzą i zgodą jednostki certyfikującej wyrób.

5) Wymienione zmiany i odstępstwa skutkują utratą certyfikatu oraz koniecznością ponownego certyfikowania wyrobu $\mathrm{w}$ aspekcie zmienionych wymagań $\mathrm{i}$ kryteriów.

6) Wnioskodawca zobowiązany jest pod groźbą utraty certyfikatu do informowania jednostki certyfikującej o wszelkich zmianach w wyrobie, które mogłyby mieć wpływ na jego jakość.

7) Jednostka certyfikująca prowadzi rejestr wydanych certyfikatów (zał.1) oraz skoroszyt dokumentacyjny dla każdego wyrobu i dokonuje okresowych przeglądów wyrobów certyfikowanych zasięgając $w$ tym celu informacji od producenta i użytkownika. W tym celu dokonuje ankietyzacji i analizy stanu wyrobu na zgodność z certyfikatem.

8) W przypadku ujawnienia odstępstw od certyfikatu oraz nadużywania wydanych dokumentów bądź nieodpowiedniej promocji wyrobu, jednostka certyfikująca przekazuje producentowi lub użytkownikowi pisemne upomnienie, informuje o konsekwencjach, cofa certyfikat podając to do publicznej wiadomości bądź kieruje sprawę na drogę sądową.

9) Jednostka Certyfikująca Wyroby wymaga od producenta wyrobu certyfikowanego:

-Przechowywania i udostępniania zapisów dotyczących reklamacji zgodności wyrobu.

-Podejmowania i dokumentowania działań w związku z reklamacjami i usterkami

wykrytymi w wyrobach, które mają wpływ na ich zgodność z certyfikatem.

\section{Nadzór nad dokumentacją, zapisami i poufno- ścią}

10.1.Przechowywanie dokumentacji związanej z certyfikacją.

Dokumentacja Systemu Zarządzania Ośrodka Certyfikacji Wyrobów oraz inne dokumenty (rysunki, analizy, obliczenia, opinie, raporty z badań itp.) są dokumentami wewnętrznymi i nie mogą być udostępnione osobom lub instytucją trzecim. Są przechowywane w wydzielonym pomieszczeniu Ośrodka Certyfikacji oraz nadzorowane poprzez spisy, rejestry dystrybucji, oraz książkę korespondencji wychodzącej i przychodzącej.

Oryginały Księgi Jakości i Procedur przechowuje Pełnomocnik ds. Jakości. Czas przechowywania dokumentów zdezaktualizowanych ustala się indywidualnie dla każdego przypadku, lecz nie krócej niż 5 lat. W zakresie przechowywania i ochrony dokumentów i plików komputerowych mają zastosowanie uregulowania obowiązujące w Instytucie, dotyczące archiwum oraz systemu komputerowego. Każdy zatrudniony przy certyfikacji podpisuje zobowiązanie do zachowania poufności.

10.2.Zachowanie poufności informacji związanych $\mathrm{z}$ certyfikacja.

Poufność dotyczy informacji technicznych i marketingowych przekazanych do Ośrodka Certyfikacji Wyrobów przez wnioskodawcę oraz ocen i decyzji podejmowanych $\mathrm{w}$ związku $\mathrm{z}$ wykonywaną certyfikacja. Przekazywanie dokumentów jest odnotowywane lub potwierdzane na kopiach pism. Pomieszczenie zawierające dokumentację jest zamykane, plombowane oraz dostępne tylko osobom upoważnionym, które podpisały deklarację poufności. 


\section{Podsumowanie}

1.W artykule skoncentrowano się na podstawowych aspektach procesu certyfikacji wyrobów w aplikacji dotyczącej pojazdów szynowych, nie omawiając ze względu na komunikatywność prezentacji aspektów wyłącznie dotyczących Systemu Zarządzania (audity, działania korygujące, przeglądy zarządzania itd.).

2.Proces certyfikacji wyrobu jest niezależnym, obiektywnym działaniem potwierdzającym za pomocą certyfikatu, ocenę zgodności wyrobu z wymaganiami, co nie jest jednoznaczne $z$ dopuszczeniem pojazdu do eksploatacji.

3.Na proces certyfikacji wyrobu składają się działania merytoryczne ujęte $\mathrm{w}$ statutowym obszarze działalności Instytutu Pojazdów Szynowych „TABOR” i leżące w kompetencjach zatrudnionych naukowców i specjalistów.

4.Działania merytoryczne Instytutu na rzecz certyfikacji wyrobów oraz dopuszczenia pojazdu do ruchu obejmują:

4.1.Badania wykonywane przez akredytowane, autoryzowane i notyfikowane laboratorium, posiadajace uznanie Kolei Niemieckich oraz będące na liście jednostek naukowo badawczych uprawnionych przez polskie Ministerstwo Infrastruktury do wykonywania badań na rzecz procedur dopuszczenia do eksploatacji pojazdów szynowych w kraju [11 ].

4.2.Opracowywanie Dokumentacji Technicznych Standardów Utrzymania dla taboru szynowego, obliczenia, analizy, opinie, oceny, ekspertyzy, dotyczące pojazdów szynowych i zespołów realizowane przez ukierunkowanych naukowców i specjalistów w certyfikowanym systemie jakości ISO, na rzecz procedur dopuszczenia do eksploatacji pojazdów szynowych w kraju [11 ].

5.Wykonywane aktualnie przez Instytut działania zgodnie z $[9,11]$ wypełniaja zakres merytoryczny certyfikacji wyrobu, stanowią czynnik stymulujący utrzymywanie wymaganego poziomu jakości i bezpieczeństwa taboru szynowego oraz dają solidne podstawy merytoryczne procesowi dopuszczania do ruchu pojazdów na sieci kolejowej, realizowanemu przez Urząd Transportu Kolejowego.

\section{Literatura:}

[1] Dyrektywa 48/96/WE w sprawie interoperacyjności transeuropejskiego systemu kolei duzych prędkości [2] Dyrektywa 2001/16/WE w sprawie interoperacyjności transeuropejskiego systemu kolei konwencjonalnej

[3] Dyrektywa 2004/50/WE zmieniajaca dyrektywy 48/96/WE i 2001/16/WE

[4] Dyrektywa 2004/49/WE w sprawie bezpieczeństwa kolei wspólnotowych

[5] Norma PN-EN 45011:2000 „Wymagania ogólne dotyczace jednostek prowadzacych systemy certyfikacji wyrobów".

[6] Ustawa z dnia 30 sierpnia 2002r. o systemie oceny zgodności (Dz. U. 2002 nr 166, poz.1360)

[7] Ustawa z dnia 29 sierpnia 2003 r. o zmianie ustawy o systemie oceny zgodności oraz zmianie niektórych ustaw (Dz. U. 3003 nr 170,poz. 1652)

[8] Ustawa z dnia 28 marca 2003r. o transporcie kolejowym - tekst jednolity (Dz. U. 2007 nr 16, poz.94)

[9] Rozporzqdzenie Ministra Infrastruktury z dnia 12 października 2005 r.w sprawie zakresu badań koniecznych do uzyskania świadectw dopuszczenia do eksploatacji typów budowli $i$ urzqdzeń przeznaczonych do prowadzenia ruchu kolejowego oraz typów pojazdów kolejowych (Dz. U. 2005 nr212, poz.1772)

[10] Przewodnik PKN-ISO/IEC Guide 67 marzec 2007 Ocena zgodności. Podstawy certyfikacji wyrobów.

[11] Rozporzqdzenie Ministra Infrastruktury z dnia 30 kwietnia $2004 r$ w sprawie świadectw dopuszczenia do eksploatacji typu budowli i urzadzeń przeznaczonych do prowadzenia ruchu kolejowego oraz typu pojazdu kolejowego. 